\title{
Recent trends in daily rainfall extremes over Montenegro (1951-2010)
}

\author{
D. Burić ${ }^{1}$, J. Luković ${ }^{2}$, B. Bajat ${ }^{3}$, M. Kilibarda ${ }^{3}$, and N. Živković ${ }^{2}$ \\ ${ }^{1}$ Institute of Hydrometeorology and Seismology of Montenegro, Podgorica, Montenegro \\ ${ }^{2}$ University of Belgrade, Faculty of Geography, Belgrade, Serbia \\ ${ }^{3}$ University of Belgrade, Faculty of Civil Engineering, Belgrade, Serbia \\ Correspondence to: J. Luković (jlukovic@gef.bg.ac.rs)
}

Received: 31 January 2015 - Published in Nat. Hazards Earth Syst. Sci. Discuss.: 10 April 2015

Revised: 28 August 2015 - Accepted: 6 September 2015 - Published: 16 September 2015

\begin{abstract}
More intense rainfall may cause a range of negative impacts upon society and the environment. In this study we analysed trends in extreme ETCCDI (Expert Team on Climate Change Detection and Indices) rainfall indices in Montenegro for the period between 1951 and 2010. Montenegro has been poorly studied in terms of rainfall extremes, yet it contains the wettest Mediterranean region known as Krivošije. Several indices of precipitation extremes were assessed including the number of dry days and rainfall totals in order to identify trends and possible changes. A spatial pattern relationship between extreme rainfall indices and the North Atlantic Oscillation has also been examined. The results generally suggest that the number of days with precipitation decreased while rainfall intensity increased, particularly in south-western parts of the country. A slight tendency towards intense rainfall events is suggested. The examined rainfall indices and North Atlantic Oscillation over Montenegro seemed to be directly linked to changes in one of the major large-scale circulation modes such as the NAO pattern that is particularly evident during the winter season.
\end{abstract}

\section{Introduction}

Rainfall extremes over the Mediterranean region are of particular interest since they can have serious environmental, societal and economic impacts. Although annual rainfall over the Mediterranean region generally decreased during the second half of the 20th century (Raiser and Kutiel, 2010; Trenberth et al., 2007), the frequency of heavy rainfall generally increased (Alpert et al., 2002; Kostopoulou and Jones, 2005;
Ducić et al., 2012). These intense periods of rainfall may have serious consequences including potential flooding, soil erosion and land degradation. Agricultural areas are sparsely distributed in this region and such hazards can have a significant impact on farming.

The Mediterranean region itself is characterized by complex patterns of inter-annual as well as intra-annual rainfall variability. Many authors have therefore studied particular Mediterranean countries or stations in relation to rainfall extremes. Rodrigo and Trigo (2007) analysed spatial patterns of rainfall extremes at annual and seasonal scales for the whole Iberian Peninsula (1951-2002) using 15 stations. They noticed a significant negative trend in daily intensity rainfall at an annual level, between -2.00 and $-5.76 \mathrm{~mm} \mathrm{day}^{-1}$, which was particularly pronounced in northern and southern stations. Extreme rainfall (defined as being beyond the 95th percentile of wet days amounts) did not reveal significant trends in most of the Iberian Peninsula. Focusing on spatial variability of rainfall extremes in southern Portugal, Durao et al. (2009) showed a slight decrease in rainfall between the 1960s and the end of the 20th century. Using observations from 105 stations, they also concluded that indices of rainfall extremes (frequency of extremely heavy precipitation events and index characterizing flood events) have shown no significant temporal trends.

A tendency towards drier conditions but also for extreme rainfall has been identified over other regions across the Mediterranean, including Italy, the Balkans, Cyprus and Israel. Alpert et al. (2002) found an increasing trend in heavy-torrential categories $\left(64-128 \mathrm{~mm} \mathrm{day}^{-1}\right)$ for the Italian Peninsula (1951-1995) and a significant decrease in 


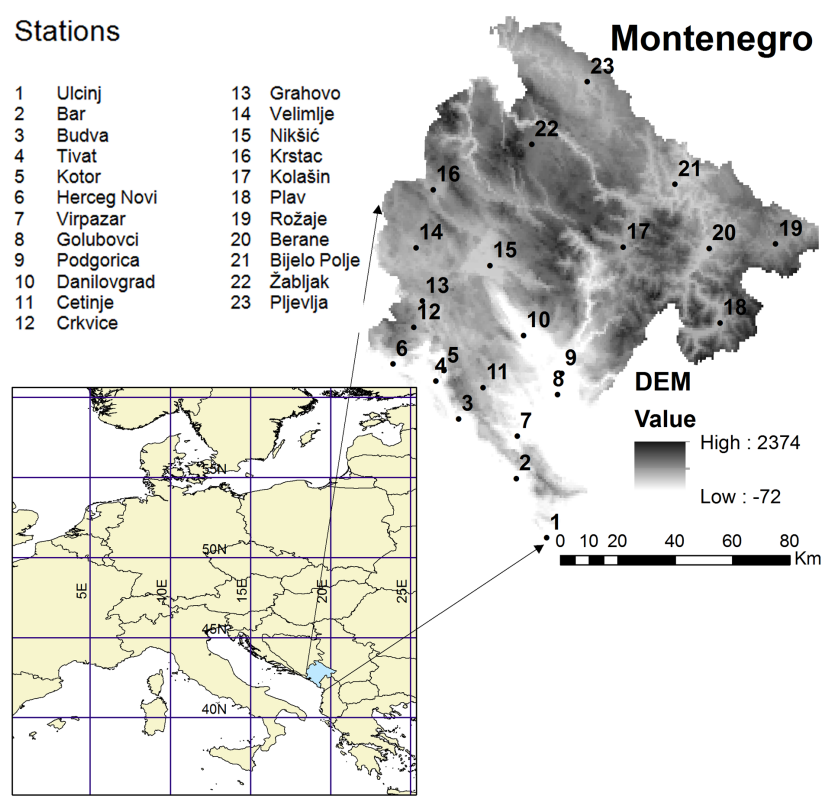

Figure 1. Locations of the stations and elevation of Montenegro.

weaker categories $\left(0-32 \mathrm{~mm} \mathrm{day}^{-1}\right)$. They also showed that heavy to torrent contribution (32-up mm day ${ }^{-1}$ ) increased from $23 \%$ from the total rainfall in the 1950 s to $31 \%$ at the end of the study period. Significant percentages of heavy rainfall events compared to total precipitation in Italy was confirmed later by Kostopoulou and Jones (2005). The same authors described a similar pattern for the western coasts of the Balkan Peninsula but with less significant results. Significant results were not found in Israel and Cyprus for the period 1951-1995 (Alpert et al., 2002). A recent study reported by Ziv et al. (2014) on trends in rainfall regime over Israel (1975-2010) showed a decrease in rain days in most of the stations located in wet and semi-arid parts but also an increase in average rainfall amounts and heavy rainfall days (> $30 \mathrm{~mm}$ ) in coastal areas (both statistically insignificant).

Montenegro so far has been poorly studied in terms of rainfall extremes. Ducić et al. (2012) examined rainfall extremes in the wettest Mediterranean region Krivošije, Montenegro and outlined their relationship to circulation types (1951-2007). Using only two stations, Herceg Novi and Crkvice, their analyses of rainfall extreme indices showed that very extreme precipitation events significantly increased by $1.8 \%$ (95\% confidence level) annually despite having significant decreases ( $99 \%$ confidence level) in the number of wet days (3.59 days annually for Crkvice and 2.97 days for Herceg Novi).

The aim of this study is to investigate trends in rainfall extreme indices over Montenegro and to better depict their spatial patterns using web mapping techniques. Following the study by Burić et al. (2011) that postulated a link between the North Atlantic Oscillation (NAO) and rainfall over Montene-

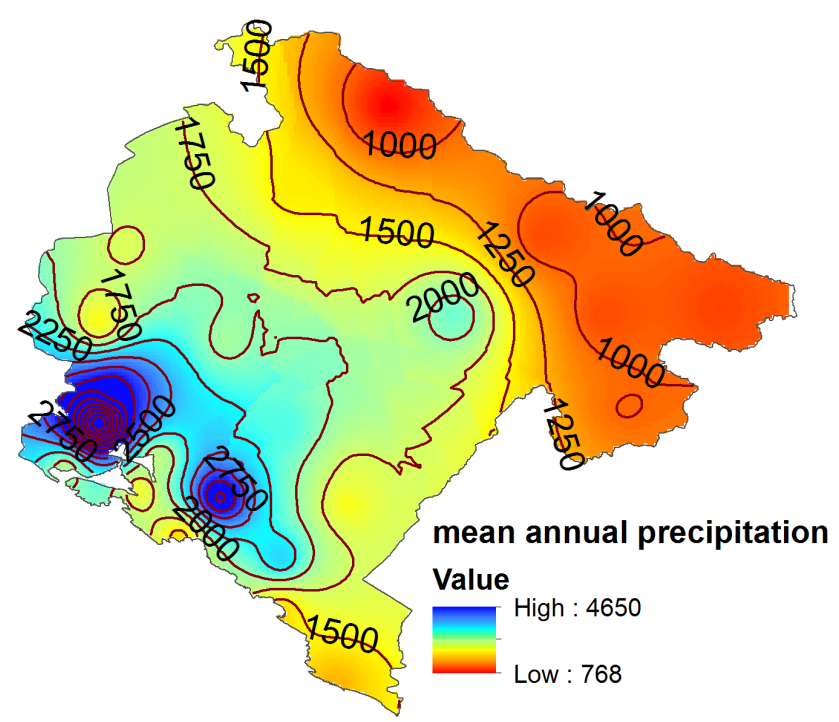

Figure 2. Isohyet map of Montenegro.

gro, here we quantify the influence of the NAO on rainfall extreme indices.

In order to approach these research questions, this paper examines annual and seasonal trends in rainfall extreme indices in Montenegro during the period between 1951 and 2010. Introductory explanations including previous investigations are given in Sect. 1. A detailed description of the study area is given in Sect. 2. Data sets and a description of methodology are presented in Sect. 3. Results and a discussion are given in Sect. 4, and concluding remarks in Sect. 5.

\section{Study area}

The study area comprises Montenegro, which covers nearly $3 \%$ of the Balkan Peninsula with an area of $13.812 \mathrm{~km}^{2}$. It has diverse topography including a narrow Adriatic coastline that stretches along the south-western part, the karst region in the central parts and the high Dinaric Mountains (above $2000 \mathrm{~m}$ ) in the northern parts of the country (Fig. 1). The coastal region is characterized by a typical Mediterranean climate while a moderate-continental climate is present in the northern parts. The average annual rainfall ranges from about $800 \mathrm{~mm}$ in the northeast (Fig. 2) to above $4000 \mathrm{~mm}$ in the mountainous areas in the west, which is the wettest part of the Mediterranean region (Ducić et al., 2012). The Crkvice meteorological station located on the south-eastern slope of the Orijen Mountain presents the highest average annual rainfall extreme $(4593 \mathrm{~mm}$ in the baseline period 1960-1990) found in Europe (http://www.ncdc.noaa.gov/oa/ climate/globalextremes.html). Such high annual rainfall is mostly due to orographic uplift (Radovanović et al., 2008). 


\section{Data and methodology}

\subsection{Data}

The rainfall data include daily totals from 23 meteorological stations in Montenegro (1951-2010) provided by the HydroMeteorological Service of Montenegro. Metadata are quality controlled in terms of correction of misprints and relocation of the stations (WMO, 2004). There were no missing data.

Data homogeneity is a basic requirement when assessing changes in rainfall extremes. However, an advanced method for analysing daily rainfall data homogeneity has not been developed yet (Toreti et al., 2010). In this study, data are carefully evaluated by applying a multiple analysis of series for homogenization (MASH v3.02) method. The MASH method was developed in the Hungarian Meteorological Service (Szentimrey, 1994, 1999, 2003); it is a relative homogeneity test that does not presume that the reference series are homogeneous (Costa and Soares, 2009). In this study, a version of MASHv3.02 extended for homogenization of daily rainfall data has been used. Portions of the time series with inhomogeneities were excluded from the analysis.

An Expert Team on Climate Change Detection and Indices (ETCCDI), supported by the World Meteorological Organization (WMO) Commission for Climatology, the Joint Commission for Oceanography and Marine Meteorology (JCOMM) and the Research Program on Climate Variability and Predictability (CLIVAR) developed the list of precipitation indices used in this study. We selected a set of five indices of rainfall extremes (Table 1) including the number of dry days and rainfall totals. The number of dry days used in this manuscript is defined as a total number of days with less than $1 \mathrm{~mm}$ of rainfall including days without rainfall within the given period. Indices are defined in terms of the numbers of days that exceed either an absolute or percentile threshold. Percentile-based indices allow spatial comparisons, as they sample the same part of the probability distribution of rainfall at each location. Day-count indices based on absolute thresholds are less suitable for spatial comparisons of extremes. The reason is that, over large areas, day-count indices based on absolute thresholds may sample very different parts of rainfall distributions (Peterson et al., 2001; Klein-Tank and Konnen, 2003; Vincent and Mekis, 2006; Gajić-Čapka, 2009; WMO, 2009; Caesar et al,. 2011).

As a proxy for the North Atlantic Oscillation, we use the NAO as the standardized atmospheric pressure between Ponta Delgada (Azores) and Akureyri (Iceland).

\subsection{Methodology}

Percentile thresholds are determined empirically from the observed data series in the standard period of 1961-1990. The procedure ensures that extreme rainfall events can occur with equal probability throughout the year (WMO, 2009).
The statistical significance of the calculated trends of the indices was tested using a Mann-Kendall test. This method has been applied because it is more suitable for nonparametric distributions. The Mann-Kendall test is used for trend analysis in ETCCDI workshops (Zhang et al., 2005). Sen's (1968) slope estimator was used for estimating trends within the indices. This is a more robust approach for the estimation of trends within the indices based on daily data (Salmi et al., 2002; Olofintoye and Sule, 2010; Šumenjak and Šuster, 2011; Mondal et al., 2012). Since the average annual rainfall in Montenegro varies a great deal from about $800 \mathrm{~mm}$ to above $4000 \mathrm{~mm}$, rainfall trend for mean rainfall, SDII and R95TOT is given in percentage per decade $\left(\% \mathrm{dec}^{-1}\right)$ using Normal 1961-1990.

Depending on the data distribution, either the parametric or nonparametric method may be used for correlation detection. In general, the nonparametric methods, e.g. Kendall's Tau Test, perform better relative to their parametric counterparts for abnormal distributions. However, due to the fact that a preliminary analysis did not show the general presence of a skewed distribution in our precipitation time series, the standard Pearson product-moment correlation coefficient has been applied.

We used a plotGoogleMaps (Kilibarda and Bajat, 2012) $R$ software package in order to obtain better insight into the spatial distribution of calculated daily rainfall extremes trends as well as their correlations to NAO over Montenegro. All maps depicting annual and seasonal values of daily rainfall extremes trends as well as correlations between rainfall extreme indices and NAO are available as interactive maps in HTML format at the web page http://osgl.grf.bg.ac. rs/materials/mne.

\section{Results and discussion}

In order to analyse extreme rainfall in Montenegro, five indices have been chosen. The analysis was performed for each of them at annual and seasonal scales. To better visualize their spatial pattern, trends of indices are depicted by bar graphs using different colours for annual and seasonal scales (Figs. 3-9). Statistically significant trends at the $95 \%$ confidence level are outlined by black lines.

The annual rainfall trend in Montenegro tends to decrease in south-western parts of the country mostly insignificantly (Fig. 3) since the only two stations (Budva $-3.6 \%$ decade $^{-1}$ and Krstac $-2.8 \%$ decade $^{-1}$ ) showed a significant decrease. The winter significant decrease (between -4.8 and $-6.6 \%$ decade $^{-1}$ ) is detected in the same parts of the country, suggesting a slight tendency towards drier conditions. Those are mainly stations near the Mediterranean coast of the country. In contrast, the northern parts showed positive annual rainfall trends that are also significant at two stations. The autumn season revealed positive trends dominating all over the territory. A similar pattern with win- 
Table 1. Definitions and abbreviations of the ETCCDI indices of precipitation extremes used in this study.

\begin{tabular}{lll}
\hline Index & Definition & Units \\
\hline SDII & $\begin{array}{l}\text { Simple Daily Precipitation Intensity Index (Annual total/Number of } \\
\text { days with precipitation } \geq 1 \mathrm{~mm}^{-1} \text { ) }\end{array}$ & $\mathrm{mm} \mathrm{dec}^{-1}$ \\
\hline R20 mm & Number of days with heavy precipitation amount above $20 \mathrm{~mm}$ & Days dec $^{-1}$ \\
\hline R75p & $\begin{array}{l}\text { Number of days with precipitation amount above a site specific thresh- } \\
\text { old value for moderate days, calculated as the 75th (R75\%) percentile of } \\
\text { the distribution of daily precipitation amounts at days with Rd } \geq 1 \mathrm{~mm} \\
\text { in the 1961-90 baseline period. }\end{array}$ & \\
& $\begin{array}{l}\text { Number of days with precipitation amount above a site specific thresh- } \\
\text { old value for very wet days, calculated as the 95th (R95\%) percentile of } \\
\text { the distribution of daily precipitation mounts at days with Rd } \geq 1 \text { mm in } \\
\text { the 1961-90 baseline period }\end{array}$ & \\
\hline R95p & $\begin{array}{l}\text { Fraction of annual total precipitation due to events exceeding the 1961- } \\
\text { 1990 95th percentile }\end{array}$ & $\%$ \\
\hline R95pTOT & \\
\hline
\end{tabular}

Definitions including formulas are available from ETCCDI website http://cccma.seos.uvic.ca/ETCCDI/.

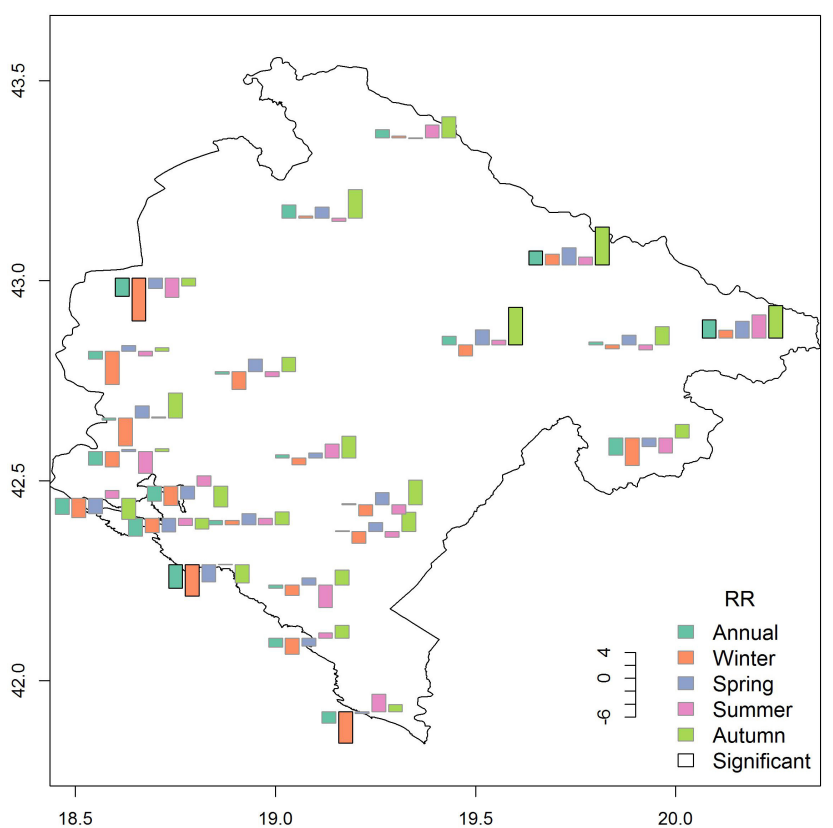

Figure 3. Decadal trends in the annual and seasonal mean precipitation (RR) in $\% \mathrm{dec}^{-1}$.

ter and spring decrease, and autumn increase in rainfall was found by Luković et al. (2013) in their rainfall trend analysis for Serbia. On the other hand, Krichak and Alpert (2005) found a rainfall decrease over the Eastern Mediterranean, which could be explained by the positive trend in the East Atlantic Western Russia (EAWR) pattern.

Drier conditions are confirmed by the number of dry days (DD) showing statistically significant increases at 13 stations (between 2.1 and 5 days decade ${ }^{-1}$ ) at annual scales (Fig. 4)

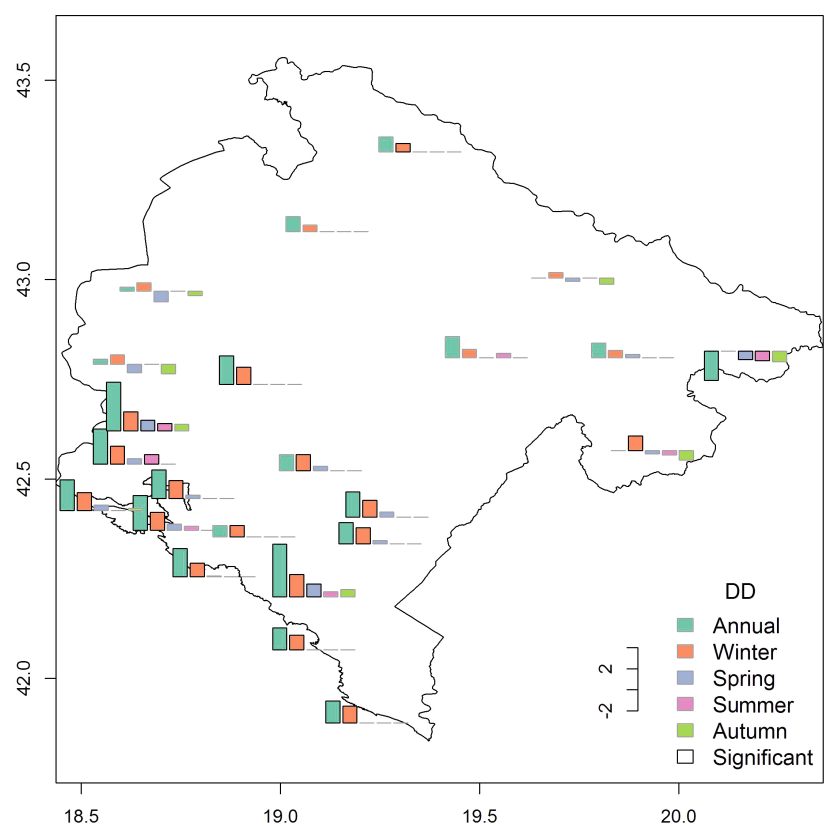

Figure 4. Decadal trends in the annual and seasonal number of dry days (DD) in days $\operatorname{dec}^{-1}$.

that are mainly distributed in the SW parts of Montenegro. Similar results are found for the winter season as well. Pronounced positive trends are found in coastal and central parts of Montenegro, highlighting the fact that Mediterranean areas may experience future drought conditions (Brandt and Thornes, 1996). Other seasons showed low statistical significance and spatial coherence.

On the other hand, the simple daily precipitation intensity index (SDII) revealed annual and seasonal increases (Fig. 5) 


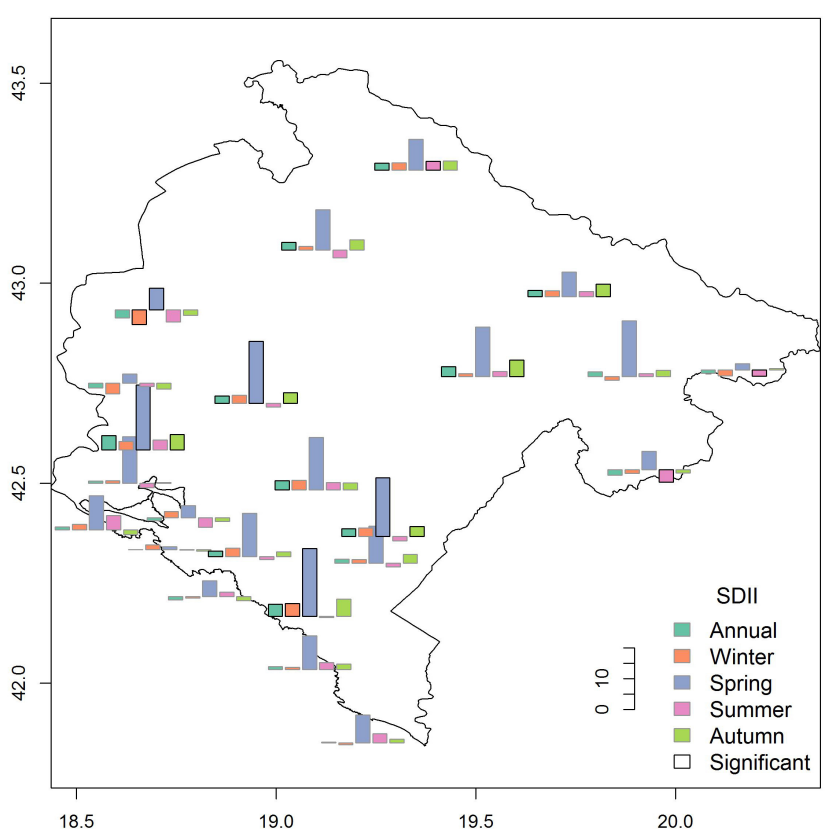

Figure 5. Decadal trends in the annual and seasonal Simple Daily Precipitation Index (SDII) in $\% \mathrm{dec}^{-1}$.

that were particularly pronounced in SW parts of Montenegro during the spring season (between 3.3 and $6.9 \% \mathrm{dec}^{-1}$ ). Kostopoulou and Jones (2005) obtained similar results for Italian stations at annual and winter scales. When comparing the results found for Italian stations, there is a lag of one season in Montenegro, pointing out that the strongest increase of SDII in Montenegro is during spring.

Trends for Montenegro in number of days with rainfall above the 75th percentile (R75p) revealed mostly negative annual values that are spread in southern and western parts of the country, with four stations being statistically significant (Fig. 6). Positive annual trends are distributed in northern and eastern areas. Results on the seasonal scale did not reveal a strong change for R75p. However, an exception arose in the summer season, showing an increase in R75p at all examined stations. However, none of these stations showed statistically significant results. On the other hand, days with rainfall events higher than the 95th percentile (R95p) also show positive trends at the annual scale mainly in central parts of Montenegro that are statistically significant at seven stations. The winter season also revealed a positive trend that was significant at four stations concentrated in the same areas as the annual ones.

Similar results are found for index R95pTOT, which is a measure of very extreme precipitation events. It showed a statistically significant positive trend at an annual scale for nine stations in Montenegro (Fig. 8). On the other hand, the summer season revealed almost half of the stations with negative trends, but were poorly significant. Kostopoulou and Jones (2005) found similar results for the Balkan Peninsula

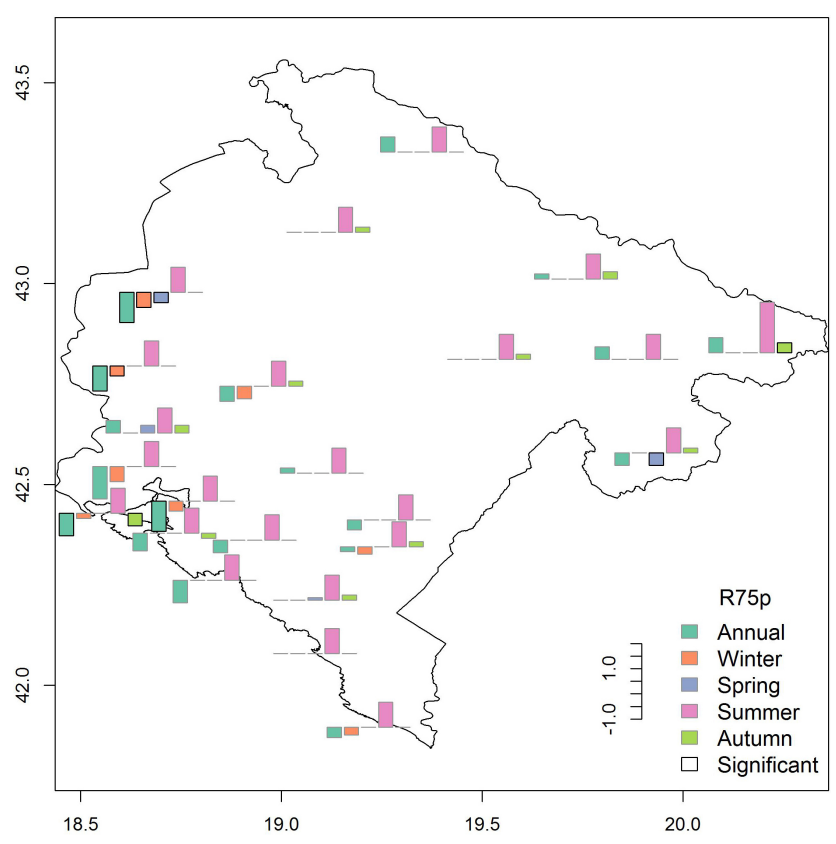

Figure 6. Decadal trends in the annual and seasonal rainfall above 75th percentile (R75p) in day $\mathrm{dec}^{-1}$.

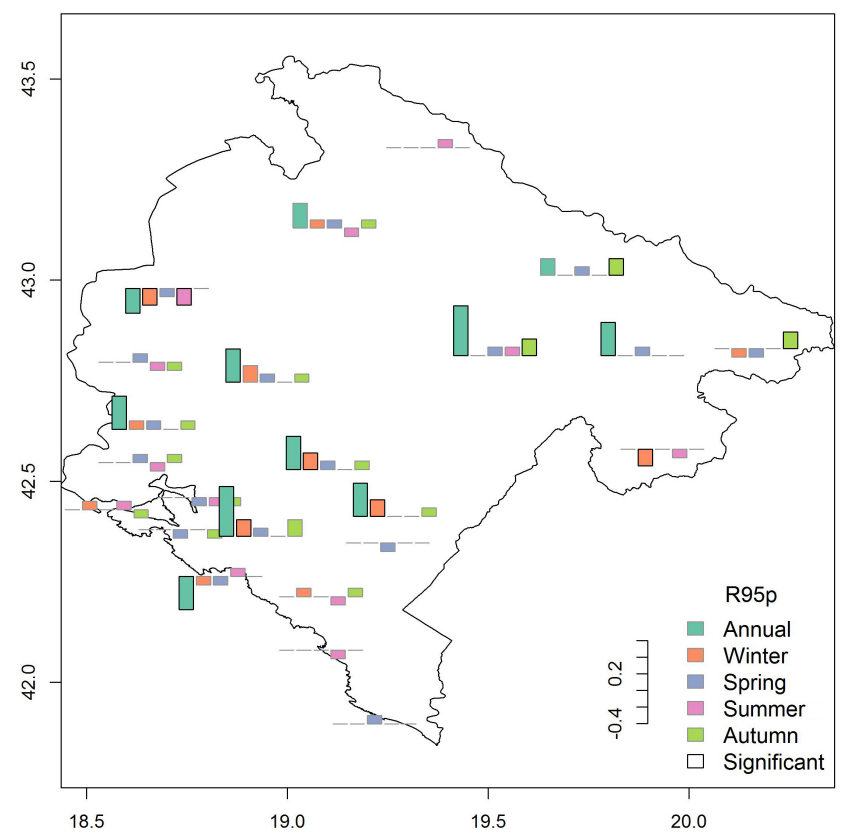

Figure 7. Decadal trends in the annual and seasonal rainfall above 95th percentile (R95p) in day dec ${ }^{-1}$.

in their study. Analysis on the seasonal scale shows that the trends are mostly weak and less significant. However, they noticed a difference between western and eastern parts of the country for the spring season, presenting opposite trends.

Extreme rainfall increased in many parts of the world (IPCC, 2013). In Montenegro, the number of days with 


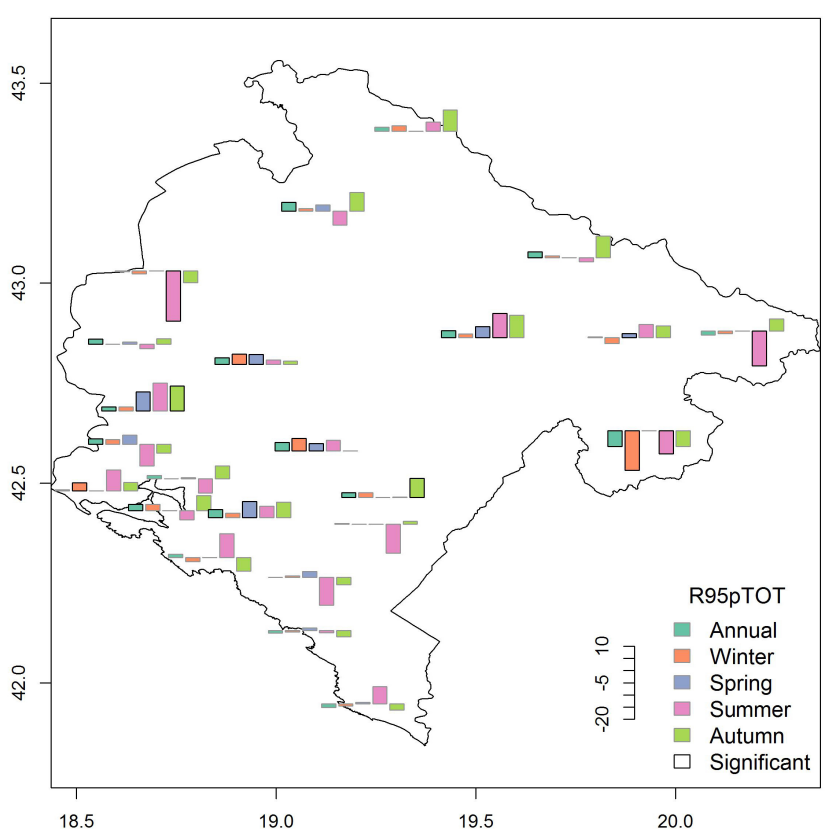

Figure 8. Decadal trends in the annual and seasonal precipitation fraction due to very wet days (R95TOT) in $\% \mathrm{dec}^{-1}$.

heavy rainfall $(\geq 20 \mathrm{~mm}$ ) decreased in the south-western parts while increases were detected in north-eastern parts of the country (Fig. 9). Results in this paper showed that stations in the Mediterranean parts of the country, which receive high annual totals, are indicating negative trends. On the other hand, northern stations with less rainfall totals are indicating positive trends.

All stations showed statistically significant negative correlations between rainfall amounts and NAO at the annual level and during the winter season (Fig. 10). During the autumn season, the majority of stations also showed statistically significant negative correlations. Many studies that analyse NAO impact show higher correlations in winter (Caloiero et al., 2011) and therefore we concentrated mainly on this season (Fearari et al., 2013). This control exerted by NAO on the rainfall during winter is related to corresponding changes in the North Atlantic storm track that affect most of western Europe (Osborn et al., 1999; Goodess and Jones, 2002) and the Eastern Mediterranean such as in Turkey (Türkeş and Erlat, 2005). None of the stations investigated provided significant correlations for spring and summer rainfall.

The number of dry days (DD) showed significant positive correlations with NAO in all stations at annual and winter levels (Fig. 11). The autumn season also suggested significant positive correlations. Krichak and Alpert (2005) found for the Mediterranean region that NAO-positive periods are wetter than normal weather over western Europe but drier than normal weather in the Mediterranean. Positive correlations between DD and NAO for Montenegro certainly confirms these assertions.

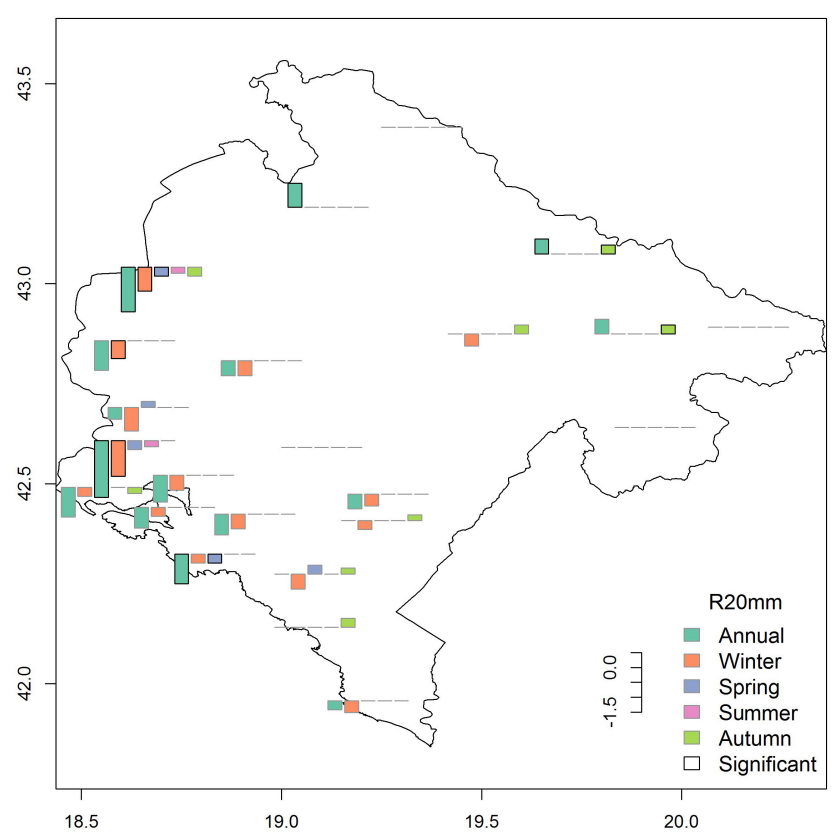

Figure 9. Decadal trends in the annual and seasonal number of days with heavy precipitation $(\mathrm{R} 20 \mathrm{~mm})$ in days $\mathrm{dec}^{-1}$.

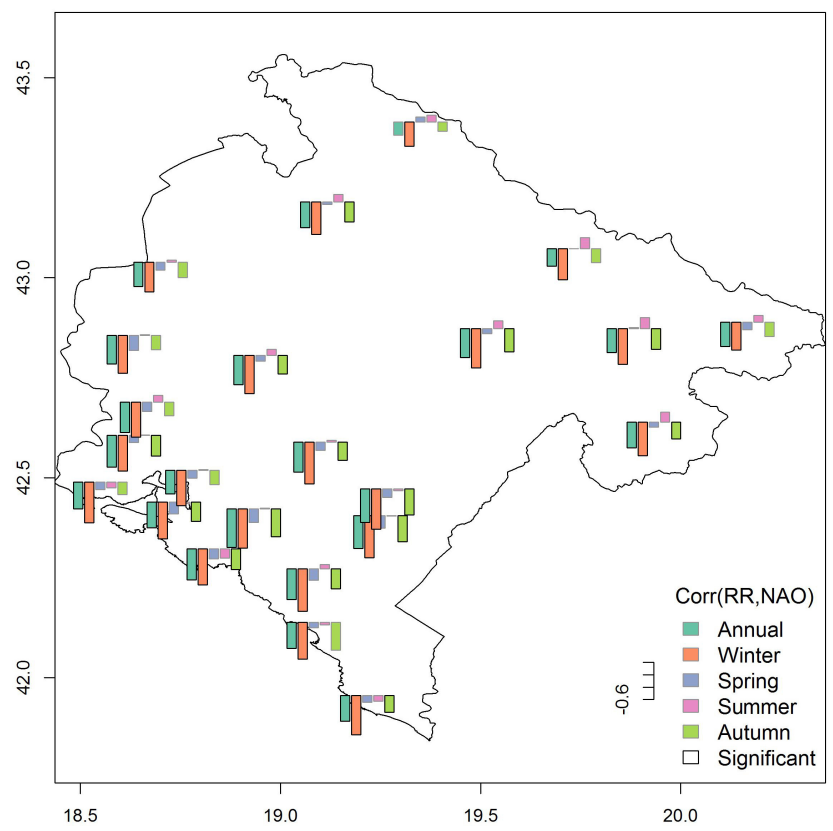

Figure 10. Mapped correlation between annual and seasonal mean precipitation (RR) and NAO index.

Simple daily precipitation intensity index (SDII) showed negative annual and winter five correlations mainly concentrated in central and eastern parts of the country. A very similar pattern is noticed in R95p. On the other hand, a quite similar distribution with significant negative correlations at the annual scale as well as during winter and the autumn season 


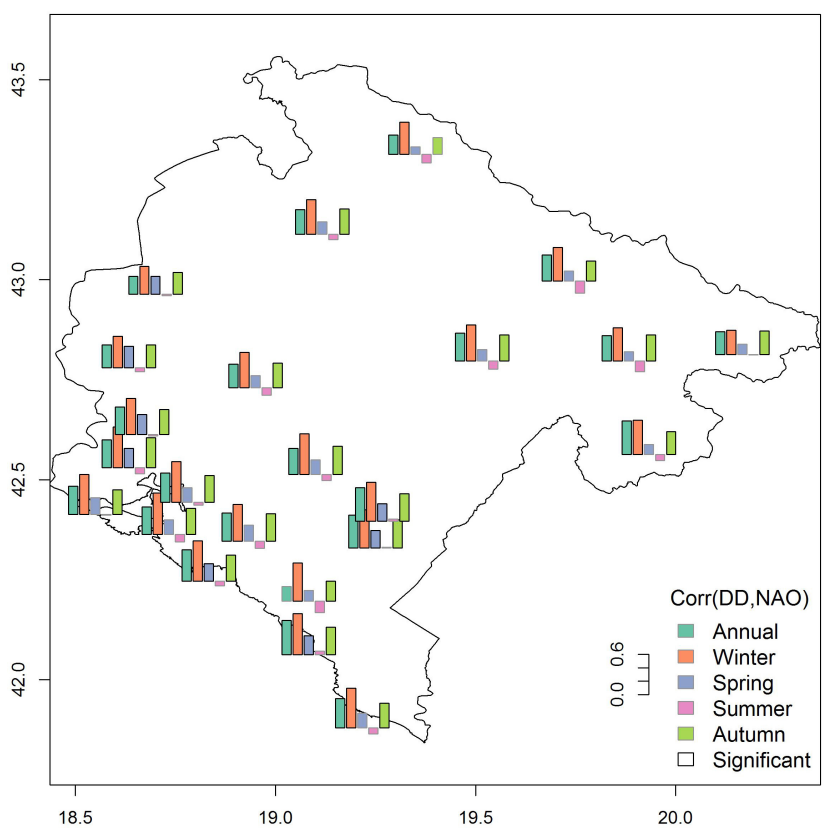

Figure 11. Mapped correlation between annual and seasonal DD and NAO index.

is noticed in R75p and R20 mm indices. The index R95pTOT did not reveal any specific spatial pattern apart from a significant negative correlation in the winter season.

\section{Conclusions}

In this paper we have studied trends in indices of rainfall extremes in Montenegro as well as their relation to North Atlantic Oscillation for the period between 1951-2010 using observations from 23 stations. This research was focused on the spatial pattern analysis of rainfall extreme indices using web-mapping tools.

The results suggested a dominant decrease in annual rainfall amounts followed by an increase in the number of dry days. Tendencies towards drier conditions are mainly pronounced in the south-western parts of the country. Despite the suggested drier conditions, precipitation intensity increased all over the country. Very extreme precipitation events indicated a particular increase in the south-western parts of the country. Such increasing tendencies of precipitation intensity on wet days in the Mediterranean part of Montenegro are suggested in IPCC (2013) reports under the scenarios of future climate change.

A spatial pattern of trend in extreme rainfall indices suggested opposite tendencies in south-western (central and coastal areas) and north-eastern parts of Montenegro (mountains). While implicating more extreme but generally drier conditions in SW parts, the eastern parts showed a slight tendency towards wetter conditions. Apart from these two opposite trends shown between the two described areas of
Montenegro, they are also characterized by different rainfall regimes. The south-western parts of the country experience a Mediterranean climate while the north-eastern parts have a continental climate. For that reason, Kutiel et al. (2014) included north-eastern Montenegrin stations into the analysis of Serbian stations while also analysing rainfall regime and its uncertainty in Serbia and Montenegro.

The results for the relationship between extreme rainfall indices and North Atlantic Oscillation over Montenegro during the investigated period seemed to be directly linked to changes in one of the major large-scale circulation modes such as NAO pattern, particularly during the winter season. This is the reason why some studies are mainly focused only on the winter part of the year (Ferrari et al., 2013) and sometimes include March (Trigo et al., 2002). That is also why some authors use a wet season concept between October and March in their analysis (Xoplaki et al., 2004).

Obtaining detailed rainfall analysis is of particular importance, especially taking into account the recent floods in 2010, 2012, and 2013 in Montenegro that caused serious damage (Burić et al., 2013, 2014).

\section{The Supplement related to this article is available online at doi:10.5194/nhess-15-2069-2015-supplement.}

Acknowledgements. This paper was realized as a part of the project "Studying climate change and its influence on the environment: impacts, adaptation and mitigation" (III 43007) financed by the Ministry of Education and Science of the Republic of Serbia within the framework of integrated and interdisciplinary research for the period 2011-2014. The study was also supported under grants No. III 47014, and TR 36035.

Edited by: H. Saaroni

\section{References}

Alpert, P., Ben-Gai, T., Baharad, A., Benjamini, Y., Yekutieli, D., Colacino, M., Diodato, L., Ramis, C., Homar, V., Romero, R., Michaelides, S., and Manes, A.: The paradoxical increase of Mediterranean extreme daily rainfall in spite of decrease in total values, Geophys. Res. Lett., 29, 1536-1539, 2002.

Brandt, J. and Thornes, J. (Eds.): Mediterranean desertification and land use, London, New York, Wiley, 554 pp., 1996.

Burić, D., Ducić, V., and Luković, J.: Kolebanje klime u Crnoj Gori u drugoj polovini XX i početkom XXI vijeka. Crnogorska akademija nauka i umjetnosti, Podgorica, 1-270, 2011 (in Serbian).

Burić, D., Ducić, V., and Mihajlović, J.: The climate of Montenegro: Modificators and types - part One, Bulletin of the Serbian Geographical Society, 93, 83-102, 2013. 
Burić, D., Ducić, V., and Mihajlović, J.: The climate of Montenegro: Modificators and types - part Two, Bulletin of the Serbian Geographical Society, 94, 73-90, 2014.

Caloiero, T., Coscarelli, R., Ferraric, E., and Mancinia, M.: Trend detection of annual and seasonal rainfall in Calabria (Southern Italy), Int. J. Climatol., 31, 44-56, 2011.

Caesar, J., Alexander, L. V., Trewin, B., Tse-ring, K., Sorany, L., Vuniyayawa, V., Keosavang, N., Shimana, A., Htay, M. M., Karmacharya, J., Jayasinghearachchi, D. A., Sakkamart, J., Soares, E., Hung, L. T., Thuong, L. T., Hue, C. T., Dung, N. T. T., Hung, P. V., Cuong, H. D., Cuong N. M., and Sirabaha, S.: Changes in temperature and precipitation extremes over the Indo-Pacific region from 1971-2005, Int. J. Climatol., 31, 791-801, 2011.

Costa, A. C. and Soares, A.: Homogenization of Climate Data: Review and New Perspectives Using Geostatistics, Mat. Geosci., 41, 291-305, 2009.

Ducic, V., Lukovic, J., Buric, D., Stanojevic, G., and Mustafic, S.: Precipitation extremes in the wettest Mediterranean region (Krivošije) and associated atmospheric circulation types, Nat. Hazards Earth Syst. Sci., 12, 687-697, doi:10.5194/nhess-12687-2012, 2012.

Durão, R., Pereira, M. J., Costa, A. C., Côrte-Real, J. M., and Soares, A.: Indices of precipitation extremes in Southern Portugal - a geostatistical approach, Nat. Hazards Earth Syst. Sci., 9, 241-250, doi:10.5194/nhess-9-241-2009, 2009.

Ferrari, E., Caloiero, T., and Coscarelli, R.: Influence of the North Atlantic Oscillation on winter rainfall in Calabria (southern Italy), Theor. Appl. Climatol., 114, 479-494, 2013.

Gajič-Čapka, M.: Trendovi oborinskih ekstrema u Crikvenici, 1901-2007. Zbornik radova-Konferencija "Suvremene metode odvodnje oborinskih voda urbanih sredina na obalnim područjima". Hrvatsko društvo za zaštiti voda, Zagreb; Građevinski fakultet sveučilišta u Rijeci, Rijeka, 166-175, 2009 (in Croatian).

Goodess, C. M. and Jones, P. D.: Links between circulation and changes in the characteristics of Iberian rainfall, Int. J. Climatol., 22, 1593-1615, 2002.

IPCC, 2013: Summary for Policymakers, in: Climate Change 2013: The Physical Science Basis. Contribution of Working Group I to the Fifth Assessment Report of the Intergovernmental Panel on Climate Change, edited by: Stocker, T. F., Qin, D., Plattner, G.K., Tignor, M., Allen, S. K., Boschung, J., Nauels, A., Xia, Y., Bex, V., and Midgley, P. M., Cambridge University Press, Cambridge, United Kingdom and New York, NY, USA.

Kilibarda, M. and Bajat, B.: PlotGoogleMaps: the R-based web mapping tool for thematic spatial data, Geomatica, 66, 7-49, 2012

Kostopoulou, E. and Jones, P. D.: Assessment of climate extremes in the Eastern Mediterranean, Meteorol. Atmos. Phys., 89, 6985, 2005.

Krichak, S. O. and Alpert, P.: Decadal trends in the East Atlantic/West Russia pattern and the Mediterranean precipitation, Int. J. Climatol., 25, 183-192, 2005.

Kutiel, H., Luković, J., and Burić, D.: Spatial and temporal variability of rain-spells characteristics in Serbia and Montenegro, International Journal of Climatology, doi:10.1002/joc.4080, 2014.

Luković, J., Bajat, B., Blagojević, D., and Kilibarda, M.: Spatial pattern of rainfall trend in Serbia, Reg. Environ. Change, 14, 1789-1799, 2014.
Mondal, A., Kundu, S., and Mukhopadhyay, A.: Rainfall trend analysis by Mann-Kendall test: A case study of norh-eastern part of cuttack distrct, Orissa. International Journal of Geology, Earth and Environmental Sciences, 2, 70-78, 2012.

Olofintoye, O. O. and Sule, B. F.: Impact of Global Warming on the Rainfall and Temperature in the Niger Delta of Nigeria, Journal of Research Information in Civil Engineering, 7, 33-48, 2010.

Osborn, T. J., Briflfa, K. R., Tett, S. F. B., Jones, P. D., and Trigo, R. M.: Evaluation of the North Atlantic Oscillation as simulated by a climate model, Clim. Dynam., 15, 685-702, 1999.

Peterson, T. C., Folland, C., Gruza, G., Hogg, W., Mokssit, A., and Plummer, N.: Report on the activities of the Working Group on Climate Change Detection and Related Rapporteurs 1998-2001. World Meteorological Organisation Rep. WMO-TD No. 1071, WCDMP-No. 47, Geneva, Switzerland, 2001.

Radovanović, M., Ducić, V., and Milovanović, B.: The climate of Orjen mountain. Advances in the studies of fauna of the Balkan Peninsula, Monograph of the Institute for Nature Conservation of Serbia, 22, 73-78, 2008.

Reiser, H. and Kutiel, H.: Rainfall uncertainty in the Mediterranean: time series, uncertainty, and extreme events, Theor. Appl. Climatol., 104, 357-375, 2010.

Rodrigo, F. S. and Trigo, R. M.: Trends in daily rainfall in the Iberian Peninsula from 1951 to 2002, Int. J. Climatol., 27, 513529, 2007.

Salmi, T., Määttä, A., Anttila, P., Ruoho-Airola, T., and Amnell, T.: Detecting trends of annual values of atmospheric pollutants by the Mann-Kendall test and Sen's slope estimates-the Excel template application MAKESENS. Helsinki: Finnish Meteorological Institute Publications on Air Quality No. 31, 2002.

Sen, P. K.: Estimates of the regression coefficient based on Kendall's tau, Journal of American Statistical Assoc., 63, 13791389, 1968.

Szentimrey, T.: Statistical problems connected with the homogenization of climatic time series, in: Climate variations in Europe, Proceedings of the European workshop held in Kirkkonummi (Majvik), edited by: Heino, R., Finland, May, Publications of the Academy of Finland, 330-339, 1994.

Szentimrey, T.: Multiple analysis of series for homogenization (MASH), in: Proceedings of the second seminar for homogenization of surface climatological data, Budapest, Hungary, WMOTD, No. 962, WCDMP No. 41, 27-46, 1999.

Szentimrey, T.: Multiple analysis of series for homogenization (MASH); Verification procedure for homogenized time series, in: Fourth seminar for homogenization and quality control in climatological databases, Budapest, Hungary, WMO-TD No. 1236, WCDMP No. 56, 193-201, 2003.

Vincent, L. A. and Mekis, É.: Changes in Daily and Extreme Temperature and Precipitation Indices for Canada over the Twentieth Century, Atmos. Ocean, 44, 177-193, 2006.

Šumenjak, K. and Šuster, V.: Parametrični in neparametrični pristopi za odkrivanje trenda $\mathrm{v}$ časovnih vrstah, Acta agriculturae Slovenica, 97, 305-312, 2011.

Toreti, A., Xoplaki, E., Maraun, D., Kuglitsch, F. G., Wanner, H., and Luterbacher, J.: Characterisation of extreme winter precipitation in Mediterranean coastal sites and associated anomalous atmospheric circulation patterns, Nat. Hazards Earth Syst. Sci. 10, 1037-1050, doi:10.5194/nhess-10-1037-2010, 2010. 
Trenberth, K. E., Jones, P. D., Ambenje, P., Bojariu, R., Easterling, D., Klein Tank, A., Parker, D., Rahimzadeh, F., Renwick, J. A., Rusticucci, M., Soden, B., and Zhai, P.: Observations: surface and atmospheric climate change, in: Climate change 2007, The physical science basis. contribution of working group I to the fourth assessment report of the intergovernmental panel on climate change, edited by: Solomon, Qin, S. D., Manning, M., Chen, Z., Marquis, M., Averyt, K. B., Tignor, M., and Miller, H. L., Cambridge University Press, Cambridge, 2007.

Trigo, R. M., Osborn, T. J., and Corte-Real, J.: The North Atlantic Oscillation influence on Europe: climate impacts and associated physical mechanisms, Clim. Res., 20, 9-17, 2002.

Türkeş, M. and Erlat, E.: Climatological responses of winter precipitation in Turkey to variability of the North Atlantic Oscillation during the period 1930-2001, Theor. Appl. Climatol., 81, 45-69, 2005.

World Meteorological Organization: Report of the CCI/CLIVAR expert team on climate change detection, monitoring and indices (ETCCDMI), Geneve, World Meteorological Organization, 2004.
World Meteorological Organization: Guidelines on Analysis of extremes in a changing climate in support of informed decisions for adaptation, Geneva 2, Switzerland, Climate Data and Monitoring WCDMP-No. 72, 2009.

Xoplaki, E., Gonzalez-Rouco, J. F., Luterbacher, J., and Wanner, H.: Wet season Mediterranean precipitation variability: influence of large-scale dynamics, Clim. Dynam., 23, 63-78, 2004.

Zhang, X., Aguilar, E., Sensoy, S., Melkonyan, H., Tagiyeva, U., Ahmed, N., Kutaladze, N., Rahimzadeh, F., Taghipour, F., Hantosh, T. H., Albert, P., Semawi, M., Ali, M. K., Al-Shabibi, M. H. S., Al-Oulan, Z., Zatari, T., Khelet, I. A. D., Hamoud, S., Sagir, R., Demircan, M., Eken, M., Adiguzel, M., Alexander, L., Peterson, T. C., and Wallis, T.: Trends in Middle East climate extreme indices from 1950 to 2003, J. Geophys. Res., 110, D22104, doi:10.1029/2005JD006181, 2005.

Ziv, B., Saaroni, H., Pargament, R., Harpaz, T., and Alpert, P.: Trends in rainfall regime over Israel, 1975-2010, and their relationship to large-scale variability, Reg. Environ. Change, 14, 1751-1764, 2014. 